\title{
Effects of a lipid-encapsulated zinc oxide dietary supplement, on growth parameters and intestinal morphology in weanling pigs artificially infected with enterotoxigenic Escherichia coli
}

\author{
Sung jae Kim, Chang Hoon Kwon ${ }^{1}$, Byung Chul Park², Chul Young Lee ${ }^{3}$ and Jeong Hee Han ${ }^{1 *}$
}

\begin{abstract}
The study was performed to investigate the effect of dietary supplementation of a lipid-encapsulated Zinc oxide on growth parameters and intestinal mucosal morphology piglets born to Duroc-sired Landrace $\times$ Yorkshire dams. Twenty-four 30-day-old piglets weaned at 25 days of age were orally challenged with $5 \times 10^{8}$ colony forming units of enterotoxigenic Escherichia coli (ETEC) K88 and fed one of the four diets for 7 days: (i) a nursery basal diet containing 100-ppm ZnO (referred to as BASAL), (ii) BASAL supplemented with 120-ppm apramycin (referred to as ANTIBIO), (iii) BASAL with 2,400-ppm ZnO (referred to as HIGH), and BASAL containing 100-ppm lipid-encapsulated ZnO (referred to as LE). All piglets were killed at the end of the experiment for histological examination on the intestine. The results showed that the average daily gain (ADG), the villus height: crypt depth (CD) ratio in the ileum, and the goblet cell density of the villus and crypt in the duodenum, jejunum, and colon were greater in the LE-fed group that those of the BASAL $(p<0.05)$. Fecal consistency score $(F C S)$ and the CD ratio in the ileum were less in the LE-fed group, compared to the BASAL-fed one $(p<0.05)$. The effects observed in the LE-fed group were almost equal to those of the HIGH-fed group as well as even superior to those of the ANTIBIO-fed group. Taken together, our results imply that dietary supplementation of 100-ppm lipid-encapsulated $\mathrm{ZnO}$ is as effective as that of 2,400-ppm ZnO for promoting growth diarrhea and intestinal morphology caused by ETEC infection.
\end{abstract}

Keywords: Diarrhea, Enterotoxigenic Escherichia coli, Growth performance, Intestine, Weaning pig, Zinc oxide

\section{Background}

Dietary supplementation of 2,000- to 3,000-ppm of zinc oxide $(\mathrm{ZnO})$ alleviates diarrhea and improves growth performance and the integrity of intestinal morphology of post-weaning piglets [1-4]. Moreover, dietary $\mathrm{ZnO}$ at those pharmacological doss exhibits the similar effects in the enterotoxigenic Escherichia coli (ETEC)-challenged piglets, which have been used as a model host for postweaning diarrhea caused by ETEC infection [5-7].

A lipid-encapsulated proprietary Zn supplement whose active component $\mathrm{ZnO}$ is supposedly released after digestion of the lipid coating by lipase in the intestinal lumen. The $\mathrm{ZnO}$ particle of the mineral supplement is more

\footnotetext{
* Correspondence: hanjh@kangwon.ac.kr

${ }^{1}$ College of Veterinary Medicine and Institute of Veterinary Science, National University, Chuncheon 200-701, Republic of Korea

Full list of author information is available at the end of the article
}

efficiently delivered to the intestine than native $\mathrm{ZnO}$ because $\mathrm{ZnO}$ contained in the former is not ionized in the stomach owing to the lipid coating [8].

We have previously reported that dietary supplementation of 100-ppm of the lipid-encapsulated $\mathrm{ZnO}$ (LE $\mathrm{ZnO}$ ) was as effective as 2,500-ppm of native $\mathrm{ZnO}$ in alleviating diarrhea and growth retardation of weanling pigs artificially challenged with $3 \times 10^{10}$ colony forming units (CFU) of ETEC K88 [9]. It is questionable, however, whether or not the supplemental LE $\mathrm{ZnO}$ would exhibit such effects comparable to those of pharmacological $\mathrm{ZnO}$ as well as antibiotics in weanling pigs with infection of ETEC, because the challenge dose of ETEC in our previous study was greater than that necessary to induce a mild clinical infection [5]. The present study was therefore undertaken to determine the effect of dietary supplementation of LE $\mathrm{ZnO}$ on growth promotion and intestinal morphology in 
weanling pigs after infection with a low infectious dose $\left(5 \times 10^{8} \mathrm{CFU}\right)$ of ETEC, compared to that of antibiotics and/or pharmacological concentration of $\mathrm{ZnO}$.

\section{Methods}

Animals and dietary treatments

The experimental protocol was approved by the Institutional Animal Care and Use Committee of Kangwon National University. Twenty-four castrated male piglets born to Duroc-sired Landrace $\times$ Yorkshire dams were randomly allocated to four $2-\mathrm{m}^{2}$ pens at weaning at 25 days of age, with six animals per pen, in the university animal research station. The animals in each pen were adapted to one of the following four experimental diets for 5 days (Table 1), (i) a nursery basal diet containing 100-ppm $\mathrm{ZnO}$ (referred to as BASAL), (ii) BASAL supplemented with 120-ppm apramycin (referred to as ANTIBIO), (iii) BASAL with 2,400-ppm $\mathrm{ZnO}$ (referred to as HIGH), and BASAL containing 100-ppm LE $\mathrm{ZnO}$ instead of 100-ppm ZnO (referred to as LE). On Day 0 of the experiment, each animal received a single oral dose of $5 \times 10^{8} \mathrm{cfu}$ of ETEC K88 in $5 \mathrm{~mL}$ of PBS (spell out). The animals were provided ad libitum with the prescribed diets and water during the 7-day experimental period after bacterial challenge. The ambient temperature, which was set at $28^{\circ} \mathrm{C}$ on Day -5 , was lowered to $25^{\circ} \mathrm{C}$ at a rate of $0.5^{\circ} \mathrm{C} /$ day. The rectal temperature of each piglet was measured on days $0,1,4$, and 7 post-inoculation. Fecal consistency was scored on days $0,1,2$, 4 , and 7 postinoculation according to the 3-notch integer scale [10-12]: 1 , well-formed feces; 2 , sloppy feces; 3 , diarrhea. To quantify fecal shedding of ETEC K88, rectal stool samples were collected from each pig on days 1,4 , and 7 postinoculation.

Table 1 Composition of the basal diet (as-fed basis)

\begin{tabular}{|c|c|}
\hline Item & Content \\
\hline \multicolumn{2}{|l|}{ Ingredient, \% } \\
\hline $\mathrm{ZnO}^{1}$ & 0.01 \\
\hline Others $^{2}$ & 999.99 \\
\hline \multicolumn{2}{|c|}{ Calculated chemical composition } \\
\hline Digestible energy, MJ/kg & 13.98 \\
\hline Crude protein, $\%$ & 16.5 \\
\hline Ether extract, \% & 3.91 \\
\hline Lysine, \% & 1.13 \\
\hline \multicolumn{2}{|c|}{$\begin{array}{l}{ }^{1} \text { Substituted by } 0.25 \% \text { uncoated } \mathrm{ZnO} \text { and } 0.01 \% \text { lipid-encapsulated } \mathrm{ZnO} \text { in the } \\
\text { high-ZnO ('HIGH') and lipid-encapsulated } \mathrm{ZnO} \text { ('LE') diets, respectively } \\
\text { (See Tables 2, 3, and 4). } \\
{ }^{2} \text { Grains-soy-whey-based ingredients, composition of which was reported } \\
\text { previously (Kwon et al., [9]). One of the four experimental diets used in the } \\
\text { present study contained } 120 \mathrm{ppm} \text { of apramycin ('ANTIBIO'). }\end{array}$} \\
\hline
\end{tabular}

\section{Collection of blood samples and intestinal tissues}

All the piglets were killed at the end of the feeding trial. Upon opening the abdominal cavity, the intestinal tract was dissected as described previously $[9,13]$. For morphological examination of the intestinal mucosa, cross-sectional segments (approximately $3 \mathrm{~cm}$ in length) were cut approximately at a $10-\mathrm{cm}$ location from the pylorus (duodenum), at $50 \%$ (jejunum) and 90\% (ileum) of the length of the small intestine, and at the transverse colon. Serum was collected after centrifugation and stored in aliquots at $-20^{\circ} \mathrm{C}$ until used.

\section{Quantification of fecal shedding of ETEC K88}

The bacterial number of ETEC K88 shed in the feces was determined by quantitative real-time PCR targeting a 70-bp fragment of the K88 fimbrial gene as described by West et al. [14]. Briefly, the genomic DNAs in the feces were extracted using QIAamp DNA Mini Kit (Qiagen, Hilden, Germany). The PCR mixture contained $2 \mu \mathrm{L}$ of DNA template, $100 \mathrm{pmol}$ of the forward primer $\left(5^{\prime}\right.$ GGTTCAGTGAAAGTCAATGCATCT-3'), 100 pmol of the reverse primer (5'-CCCCGTCCGCAGAAGTA AC-3'), $0.5 \mu \mathrm{L}$ of the probe (Cy5-5'-CCACCTCTCCC TAACACACCGGCAT-3'-BHQ2; GenoTech, Daejeon, Korea), and $12.5 \mu \mathrm{L}$ of Premix EX Taq DNA polymerase (Takara Bio, Shiga, Japan) in a total volume of $25 \mu \mathrm{L}$. Thermal cycling was performed with an initial denaturation at $95^{\circ} \mathrm{C}$ for $10 \mathrm{~min}$, followed by 45 cycles of $95^{\circ} \mathrm{C}$ for $20 \mathrm{sec}, 62^{\circ} \mathrm{C}$ for $30 \mathrm{sec}$, and $72^{\circ} \mathrm{C}$ for $30 \mathrm{sec}$. The cfu of ETEC K88 in each fecal sample was assessed from the standard curve for the ETEC K88 standard solution plotted against the threshold $(\mathrm{Ct})$ value using the Smartcycler software (Cepheid, Sunnyvale, CA).

\section{Histological examination}

The cross-sectional segments of the small and large intestines were fixed for $48 \mathrm{hrs}$ in a 10\% neutral formalin solution. The fixed tissues were embedded in paraffin and sliced to a thickness of $4 \mu \mathrm{m}$, after which the thin sections were mounted on glass slides and stained with hematoxylin/eosin for microscopic examination of the mucosal structure as previously described [13]. For determination of the goblet cell density, the specimens were stained with periodic acid-Schiff and Alcian Blue to count the neutral mucin- and acid mucin-secreting goblet cells, respectively, as described by Uni et al. [15]. The villus height $(\mathrm{VH})$, crypt depth $(\mathrm{CD})$, and the goblet cell number were determined on four well-oriented structures under a 400-fold magnified microscopic field using the Diagnostic Insight visual analysis program (Olympus, Tokyo, Japan) as described previously [9]. In each variable, the average of four measurements was taken as an observation. 


\section{Statistical analysis}

Data were analyzed as a completely randomized design using the MIXED procedure of SAS (SAS Inst. Inc., Cary, NC, USA). The model included the dietary treatment as the main effect as well as the day and its interaction with treatment in the analysis of repeated measurements. Effects of the treatment and day including its interaction with treatment were tested using the animal and day $x$ animal nested within treatment as error terms, respectively. Means were separated by the probability difference (PDIFF) option.

\section{Results}

The rectal temperature of the post-weaning pigs increased after the oral challenge with ETEC K88 and remained elevated $(P<0.05)$ during the 7 -day experimental period post-challenge (Table 2). The mean temperature of the piglets was lowered by feeding LE when compared with that of the animals provided with BASAL (Table 2). However, the mean rectal temperature of the LE-fed group did not differ from those of the ANTIBIO- and HIGH-fed groups (Table 2).

Table 2 Effects of dietary supplementations of 100 ppm of $\mathrm{ZnO}$ without (BASAL) or with 120 ppm of apramycin (ANTIBIO), 2,500 ppm of ZnO (HIGH), and 100 ppm of the lipid-encapsulated $\mathrm{ZnO}$ (LE) on clinical signs of post-weaning pigs challenged with $5 \times 10^{8}$ cfu of ETEC K88

\begin{tabular}{|c|c|c|c|c|c|c|}
\hline Item & BASAL & ANTIBIO & HIGH & LE & SEM & $P$-value \\
\hline \multicolumn{7}{|c|}{ Rectal temperature, ${ }^{\circ} \mathrm{C}$} \\
\hline D 0 & 38.48 & 38.52 & 38.50 & 38.48 & $0.15^{x}$ & \\
\hline D 1 & $39.85^{\mathrm{a}}$ & $39.47^{\mathrm{ab}}$ & $39.22^{b}$ & $39.57^{\mathrm{ab}}$ & & \\
\hline D 4 & $40.08^{\mathrm{a}}$ & $39.43^{b c}$ & $39.22^{c}$ & $39.63^{b}$ & & \\
\hline D 7 & $39.75^{\mathrm{a}}$ & $39.32^{b}$ & $38.98^{b c}$ & $38.85^{c}$ & & \\
\hline Overall ${ }^{1}$ & $39.54^{\mathrm{a}}$ & $39.18^{b}$ & $38.98^{b}$ & $39.13^{\mathrm{b}}$ & 0.10 & $<0.01$ \\
\hline
\end{tabular}

Fecal consistency score ${ }^{2}$

$\begin{array}{lllllll}\text { D } 0 & 1.50 & 1.67 & 1.83 & 1.50 & & \\ \text { D 1 } & 2.83 & 2.67 & 2.33 & 2.50 & & \\ \text { D 2 } & 2.67 & 2.83 & 2.33 & 2.50 & 0.22^{\mathrm{x}} & \\ \text { D 4 } & 2.50^{\mathrm{a}} & 2.17^{\mathrm{a}} & 2.17^{\mathrm{a}} & 1.50^{\mathrm{b}} & & \\ \text { D 7 } & 2.50^{\mathrm{a}} & 1.83^{\mathrm{b}} & 1.67^{\mathrm{b}} & 1.67^{\mathrm{b}} & & \\ \text { Overall } & 2.40^{\mathrm{a}} & 2.23^{\mathrm{ab}} & 2.07^{\mathrm{b}} & 1.93^{\mathrm{b}} & 0.11 & 0.04 \\ \text { Fecal shedding of E. coli, } \text { Log }_{10} \text { cfu/g feces } & & & \\ \text { D 1 } & 7.00^{\mathrm{a}} & 5.90^{\mathrm{b}} & 5.35^{\mathrm{b}} & 5.58^{\mathrm{b}} & & \\ \text { D 4 } & 6.86^{\mathrm{a}} & 5.71^{\mathrm{b}} & 5.22^{\mathrm{bc}} & 4.83^{\mathrm{c}} & 0.29^{\mathrm{x}} & \\ \text { D 7 } & 7.33^{\mathrm{a}} & 5.50^{\mathrm{b}} & 4.91^{\mathrm{bc}} & 4.25^{\mathrm{c}} & & \\ \text { Overall } & 7.06^{\mathrm{a}} & 5.70^{\mathrm{b}} & 5.16^{\mathrm{b}} & 4.89^{\mathrm{b}} & 0.33 & <0.01\end{array}$

${ }^{1} P$-values for the day and day $\times$ treatment were $<0.01$ and 0.04 , respectively.

${ }^{2} 1$, well-formed feces; 2 , sloppy feces; 3 , diarrhea.

${ }^{3} P$-values of the day and day $\times$ treatment were $<0.01$ and 0.25 , respectively.

${ }^{4} P$-values of the day and day $\times$ treatment were 0.09 and 0.22 , respectively.

${ }^{\mathrm{x}}$ Applies to all day $\times$ treatment combinations.

${ }^{a-c}$ Means with no common superscript within a row differ $(P<0.05)$.
The FCS was also elevated on Day 1 and 2 above that on Day 0 , but returned to the pre-challenge level by $\mathrm{d} 7$ (Table 2). The mean FCS was less in the LE-fed group than in the BASAL- and ANTIBIO-fed groups, but it did not differ between the former and HIGH-fed groups. The mean level of excretion of ETEC K88 to feces expressed as $\log$ cfu also was less in the LE-fed group, compared to the BASAL- and ANTIBIO-fed groups, not being different between the former and the HIGH-fed group.

The ADG of the animals was reduced after the ETEC challenge when compared with that during the prechallenge period (Table 3). The ADG during the experimental period was greater in the LE-fed group than in the BASAL, but it did not differ between the former and either of the ANTIBIO- and HIGH-fed groups.

The densities of goblet cells in the villus and crypt of the duodenum were greater in the LE-fed group than in the BASAL- and ANTIBIO-fed groups, whereas the villlus and crypt goblet cell densities did not differ between the LE- and HIGH-fed groups (Table 4). The goblet cell density in the villus and crypt of the jejunum was greater in the LE-fed group than in any other group, but in the ileum, it did not differ across the treatments. In the colon, it was greater in the LE-fed group than the BASAL- and ANTIBIO-fed groups, not being different between the LE- and HIGH-fed groups.

The $\mathrm{VH}, \mathrm{CD}$ and $\mathrm{VH}: \mathrm{CD}$ ratio in the duodenum were not influenced significantly by the dietary treatment (Table 4). The CD in the jejunum was less in the LE-fed group than in the BASAL- and ANTIBIO-fed groups whereas it did differ between the LE- and HIGH-fed groups. In the ileum, the $\mathrm{VH}: \mathrm{CD}$ ratio was greater in the LE-fed group than in the BASAL- and ANTIBIO-fed groups, but it did not differ between the former and the HIGH-fed group.

Table 3 Effects of dietary supplementations of 100 ppm of $\mathrm{ZnO}$ without (BASAL) or with $120 \mathrm{ppm}$ of apramycin (ANTIBIO), 2,500 ppm of ZnO (HIGH), and $100 \mathrm{ppm}$ of the lipid-encapsulated ZnO (LE) on growth performance of weanling pigs challenged with $5 \times 10^{8}$ cfu of ETEC K88

\begin{tabular}{|c|c|c|c|c|c|c|}
\hline Item & BASAL & ANTIBIO & $\mathrm{HIGH}$ & LE & SEM & $P$-value \\
\hline \multicolumn{7}{|c|}{ Before the ETEC K88 challenge $(d-5 \text { to } d 0)^{1}$} \\
\hline Initial wt, kg & 7.06 & 6.78 & 6.91 & 6.57 & 0.28 & 0.65 \\
\hline Final wt, kg & 7.88 & 7.56 & 7.74 & 7.40 & 0.31 & 0.72 \\
\hline$A D G, g$ & 165 & 156 & 166 & 166 & 11 & 0.91 \\
\hline \multicolumn{7}{|c|}{ After the ETEC K88 challenge $(\mathrm{d} 0 \text { to } \mathrm{d} 7)^{1}$} \\
\hline Final wt, kg & 8.43 & 8.32 & 8.66 & 8.36 & 0.36 & 0.91 \\
\hline$A D G, g$ & $78^{b}$ & $109^{\mathrm{ab}}$ & $132^{a}$ & $137^{\mathrm{a}}$ & 14 & 0.03 \\
\hline
\end{tabular}

${ }^{1}$ The ADFI of the animals, which were group-fed, were $236,233,224$, and $240 \mathrm{~g}$ during the pre-challenge period and $324,386,350$, and $370 \mathrm{~g}$ during the post-challenge period in BASAL, ANTIBIO, HIGH, and LE, respectively.

${ }^{\mathrm{a}, \mathrm{b}}$ Means with no common superscript within a row differ $(P<0.05)$. 
Table 4 Effects of dietary supplementations of $100 \mathrm{ppm}$ of $\mathrm{ZnO}$ without (BASAL) or with $120 \mathrm{ppm}$ of apramycin (ANTIBIO), 2,500 ppm of ZnO (HIGH), and $100 \mathrm{ppm}$ of the lipid-encapsulated ZnO (LE) on histological measurements of the intestine in weanling pigs challenged with $5 \times 10^{8}$ cfu of ETEC K88

\begin{tabular}{|c|c|c|c|c|c|c|}
\hline Item & BASAL & ANTIBIO & $\mathrm{HIGH}$ & LE & SEM & $P$-value \\
\hline \multicolumn{7}{|c|}{ Goblet cell density, cells $/ \mathrm{mm}^{2}$} \\
\hline \multicolumn{7}{|c|}{ Duodenum } \\
\hline Villus & $143^{b}$ & $145^{\mathrm{b}}$ & $230^{a}$ & $211^{a}$ & 13.2 & $<0.01$ \\
\hline Crypt & $215^{\mathrm{b}}$ & $221^{\mathrm{b}}$ & $377^{\mathrm{a}}$ & $356^{\mathrm{a}}$ & 24.3 & $<0.01$ \\
\hline \multicolumn{7}{|l|}{ Jejunum } \\
\hline Villus & $102^{d}$ & $134^{c}$ & $164^{\mathrm{b}}$ & $192^{\mathrm{a}}$ & 9.1 & $<0.01$ \\
\hline Crypt & $241^{c}$ & $260^{c}$ & $305^{b}$ & $349^{a}$ & 11.1 & $<0.01$ \\
\hline \multicolumn{7}{|l|}{ Ileum } \\
\hline Villus & 187 & 196 & 192 & 183 & 18.7 & 0.97 \\
\hline Crypt & 409 & 403 & 439 & 428 & 15.0 & 0.32 \\
\hline \multicolumn{7}{|l|}{ Colon } \\
\hline Mucosa & $475^{b}$ & $515^{\mathrm{b}}$ & $624^{\mathrm{a}}$ & $675^{\mathrm{a}}$ & 32.8 & $<0.01$ \\
\hline \multicolumn{7}{|c|}{ Mucosal morphology } \\
\hline \multicolumn{7}{|c|}{ Duodenum } \\
\hline$V H^{1}, \mu m$ & 367 & 386 & 424 & 435 & 19 & 0.07 \\
\hline$C D^{2}, \mu \mathrm{m}$ & 254 & 252 & 262 & 256 & 11 & 0.93 \\
\hline $\mathrm{VH}: \mathrm{CD}$ & 1.45 & 1.53 & 1.62 & 1.72 & 0.08 & 0.10 \\
\hline \multicolumn{7}{|l|}{ Jejunum } \\
\hline $\mathrm{VH}, \mu \mathrm{m}$ & 331 & 340 & 305 & 336 & 17 & 0.52 \\
\hline$C D, \mu m$ & $257^{\mathrm{a}}$ & $255^{a}$ & $200^{b}$ & $205^{b}$ & 17 & 0.04 \\
\hline $\mathrm{VH}: \mathrm{CD}$ & 1.31 & 1.41 & 1.52 & 1.64 & 0.10 & 0.12 \\
\hline \multicolumn{7}{|l|}{ Ileum } \\
\hline $\mathrm{VH}, \mu \mathrm{m}$ & 297 & 300 & 295 & 305 & 9 & 0.89 \\
\hline$C D, \mu \mathrm{m}$ & 250 & 239 & 229 & 224 & 7 & 0.06 \\
\hline $\mathrm{VH}: \mathrm{CD}$ & $1.19^{\mathrm{a}}$ & $1.26^{\mathrm{a}}$ & $1.29^{\mathrm{ab}}$ & $1.36^{\mathrm{b}}$ & 0.03 & 0.02 \\
\hline
\end{tabular}

${ }^{1} \mathrm{VH}=$ villus height.

${ }^{2} \mathrm{CD}=$ crypt depth.

${ }^{a-d}$ Means with no common superscript within a row differ $(P<0.05)$.

\section{Discussion}

The piglets challenged with $5 \times 10^{8} \mathrm{cfu}$ of ETEC K88 exhibited expected responses to both ANTIBIO and $\mathrm{HIGH}$, with decreases in rectal temperature, FCS, and fecal ETEC shedding and increases in ADG and goblet cell density. Moreover, the effects of LE were virtually equal to those of HIGH, which were equal to or greater than those of ANTIBIO. The ADG of the experimental groups were thus reflective of their ETEC infection status, suggesting that the greater weight gain in the LE- and HIGH-fed groups, compared to the BASAL, resulted from the antibacterial activities of the former. Overall, the present results for the ANTIBIO- and HIGH-fed groups were consistent with published reports regarding the effects of apramycin with or without other antibiotics
$[12,16,17]$ as well as pharmacological $\mathrm{ZnO}[1,7,18]$. Furthermore, the effects of HIGH and LE-BASAL, compared to BASAL, observed in the present study were very similar to our previous results in post-weaning pigs challenged with $3 \times 10^{10} \mathrm{cfu}$ of ETEC K88 [9], suggesting that LE and $\mathrm{HIGH}$ are equally effective for alleviating the ETEC infection.

The $\mathrm{VH}, \mathrm{CD}$, and $\mathrm{VH}: \mathrm{CD}$ of the intestinal mucosa of the ETEC-infected piglets did not change in response to HIGH or LE, except for a decrease in CD in the jejunum and an increase in the $\mathrm{VH}: \mathrm{CD}$ ratio in the ileum. These results were substantially different from the almost consistent increase in $\mathrm{VH}$ and $\mathrm{VH}: \mathrm{CD}$ and decrease in $\mathrm{CD}$ in response to both HIGH and LE in the jejunum and ileum in post-weaning pigs challenged with a high dose of ETEC K88 in our previous study [9]. Regarding the effects of supplemental $\mathrm{ZnO}$ on intestinal mucosal morphology of the piglets in the literature, the $\mathrm{VH}$ and $\mathrm{VH}: \mathrm{CD}$ increased and $\mathrm{CD}$ decreased inconsistently in response to pharmacological $\mathrm{ZnO}$ in $\mathrm{Li}$ et al. $[19,20]$ and OwusuAdiedu et al. [18], but in Hedemann et al. [21], the VH decreased due to supplemental $\mathrm{ZnO}$. Collectively, these results suggest that the beneficial effects of supplemental $\mathrm{ZnO}$ on the structural integrity of intestinal mucosa are more pronounced when the piglets are severely infected with ETEC than when moderately infected.

\section{Conclusions}

The present results indicated that dietary supplementation of $72 \mathrm{ppm} \mathrm{Zn}$ as $\mathrm{LE} \mathrm{ZnO}$ was as effective as that of 2,000 to 2,500 $\mathrm{ppm} \mathrm{Zn}$ provided as native $\mathrm{ZnO}$ or antibiotics for increasing growth performance, goblet cell density in the intestine as well as reducing diarrhea in weanling pigs challenged with a low dose of ETEC K88. More studies are necessary, however, to determine the effects of $\mathrm{LE} \mathrm{ZnO}$ relative to those of native $\mathrm{ZnO}$ on those responses examined in the present study in naïve weanling pigs under production conditions.

\section{Competing interests}

The authors declare that they have no competing interests.

\section{Authors' contributions}

$\mathrm{HJH}, \mathrm{PBC}$ and $\mathrm{CYL}$ designed the experiment and analyzed the data. KSJ and $\mathrm{KCH}$ managed the experimental animals and carry out the experiments for evaluation. All authors read and approved the final manuscript.

\section{Acknowledgements}

This study was financially supported by CTCBIO, Inc. and the Regional Animal Industry Center at Gyeongnam National University of Science and Technology.

\section{Author details}

${ }^{1}$ College of Veterinary Medicine and Institute of Veterinary Science, National University, Chuncheon 200-701, Republic of Korea. ${ }^{2}$ R \& D Institute, Sunjin Co., Ltd, 517-3 Doonchon-dong, Kangdong-gu, Seoul 134-060, Republic of Korea. ${ }^{3}$ The Regional Animal Industry Center, Gyeongnam National University of Science and Technology, Jinju 660-758, Republic of Korea. 
Received: 17 October 2014 Accepted: 29 December 2014

Published online: 24 January 2015

\section{References}

1. Hill GM, Mahan DC, Carter SD, Cromwell GL, Ewan RC, Harrold RL, et al. Effect of pharmacological concentrations of zinc oxide with or without the inclusion of an antibacterial agent on nursery pig performance. J Anim Sci. 2001;79:934-41.

2. Heo JM, Opapeju FO, Pluske JR, Kim JC, Hampson DJ, Nyachoti CM. Gastrointestinal health and function in weaned pigs: a review of feeding strategies to control post-weaning diarrhoea without using in-feed antimicrobial compounds. J Anim Physiol Anim Nutr. 2013;97:207-37.

3. Hill GM. Minerals and mineral utilization in swine. In: Chiba LI, editor. Sustainable swine nutrition. Oxford, UK: John Wiley \& Sons, Inc.; 2013. p. 173-95.

4. Willing BP, Malick G, Van Kessel AG. Nutrition and gut health in swine. In: Chiba LI, editor. Sustainable swine nutrition. Oxford, UK: John Wiley \& Sons, Inc.; 2013. p. 197-213.

5. Madec F, Bridoux N, Bounaix S, Cariolet R, Duval-Iflah Y, Hampson DJ, et al. Experimental models of porcine post-weaning colibacillosis and their relationship to post-weaning diarrhoea and digestive disorders as encountered in the field. Vet Microbiol. 2000;72:295-310.

6. Wellock IJ, Fortomaris PD, Houdijk JGM, Kyriazakis I. Effects of dietary protein supply, weaning age and experimental enterotoxigenic Escherichia coli infection on newly weaned pigs: health. Animal. 2008;2:834-42.

7. Slade RD, Kyriazakis I, Carroll SM, Reynolds FH, Wellock IJ, Broom LJ, et al. Effect of rearing environment and dietary zinc oxide on the response of group-housed weaned pigs to enterotoxigenic Escherchia coli 0149 challenge. Animal. 2011;5:1170-8.

8. Kim JC, Hansen CF, Pluske JR, Mullan BP. Evaluating the replacement of zinc oxide with an encapsulated zinc oxide product as a means of controlling post-weaning diarrhea in piglets. Project 2C-114. Pork CRC. 2010. p. 1-16.

9. Kwon CH, Lee CY, Han SJ, Kim SJ, Park BC, Jang I, et al. Effects of dietary supplementation of lipid-encapsulated zinc oxide on colibacillosis, growth and intestinal morphology in weaned piglets challenged with enterotoxigenic Escherichia coli. Anim Sci J. 2014;85:805-13.

10. Heo JM, Kim JC, Hansen CF, Mullan BP, Hampson DJ, Pluske JR. Feeding a diet with decreased potein content reduces indices of protein fermentation and the incidence of postweaning diarrhea in weaned pigs challenged with an enterotoxigenic strain of Escherichia coli. J Anim Sci. 2009;87:2833-43.

11. Yan $L$, Jang HD, Kim $I H$. Effects of varying creep feed duration on preweaning and post-weaning performance and behavior of piglet and sow. Asian-Aust J Anim Sci. 2011;24:1601-6.

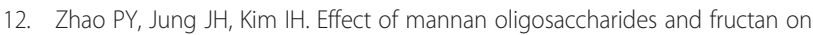
growth performance, nutrient digestibility, blood profile, and diarrhea score in weanling pigs. J Anim Sci. 2012;90:833-9.

13. Lee CY, Lim Y-W, Ko Y-H, Kang S-Y, Park MJ, Ko T, et al. Intestinal growth and deveopment of weanling pigs in response to dietay supplementation of antibiotics, phytogenic products and brewer's yeas plus Bacillus spores. J Anim Sci Technol. 2011;53:227-35.

14. West DM, Sprigings KA, Sassar C, Wakeley PR, Sawyer J, Davies RH. Rapid detection of Escherichia coli virulence factor genes using multiplex real-time TaqMan $^{\circledast}$ PCR assays. Vet Microbiol. 2007;122:323-31.

15. Uni Z, Smirnov A, Sklan D. Pre- and posthatch development of goblet cells in the broiler small intestine: effect of delayed access to feed. Poultry Sci. 2003;82:320-7.

16. Jin Z, Yang YX, Choi JY, Shinde PL, Yoon SY, Hahn T-W, et al. Potato (Solanum tuberosum L. Cv. Gogu valley) protein as a novel antimicrobial agent in weanling pigs. J Anim Sci. 2008;86:1562-72.

17. Lee JS, Awji EG, Lee SJ, Tassew DD, Park YB, Park KS, et al. Effect of Lactobacillus plantarum CJLP243 on the growth performance and cytokine response of weanling pigs challenged with enterotoxigenic Esherichia coli. J Anim Sci. 2012;90:3709-17.

18. Owusu-Asiedu A, Nyachoti CM, Marquardt RR. Response of early-weaned pigs to an enterotoxigenic Escherichia coli (K88) challenge when fed diets containing spray-dried porcine plasma or pea protein isolate plus egg yolk antibody, zinc oxide, fumaric acid, or antibiotic. J Anim Sci. 2003;81:1790-8.

19. Li BT, Van Kessel AG, Caine WR, Huang SX, Kirkwood RN. Small intestinal morphology and bacterial populations in ileal digesta and feces of newly weaned pigs receiving a high dietay level of zinc oxide. Can J Anim Sci. 2001;81:511-6.
20. Li X, Yin J, Li D, Chen X, Zang J, Zhou X. Dietary supplementation with zinc oxide increases IGF-I and IGF-I receptor gene expression in the small intestine of weanling piglets. J Nutr. 2006;136:1786-91.

21. Hedemann MS, Jensen BB, Poulsen HD. Influence of dietary zinc and copper on digestive enzyme activity and intestinal morphology in weaned pigs. J Anim Sci. 2006;84:3310-20.

\section{Submit your next manuscript to BioMed Central and take full advantage of:}

- Convenient online submission

- Thorough peer review

- No space constraints or color figure charges

- Immediate publication on acceptance

- Inclusion in PubMed, CAS, Scopus and Google Scholar

- Research which is freely available for redistribution 